\title{
The Effect of Higher Education on Entrepreneurial Activities and Starting Up Successful Businesses
}

\author{
Jan Hunady, Marta Orviska, Peter Pisar
}

\author{
Matej Bel University in Banska Bystrica \\ Tajovskeho 10 \\ 97590 Banska Bystrica, Slovakia \\ E-mail.jan.hunady@umb.sk,marta.orviska@umb.sk,peter.pisar@umb.sk \\ cross $^{\text {ref }}$ http://dx.doi.org/10.5755/j01.ee.29.2.19069
}

\begin{abstract}
The paper deals with the potential relationship between higher education and entrepreneurial activities. Universities and other higher education institutions could be seen as boosting entrepreneurship in the region. University graduates could be more often involved in starting up a new business and the university itself could commercialize their innovations by creating academic spin-off companies. The paper aims to examine the potential effect of higher education on the probability of starting a business as well as its further success. Based on the data for $40 \mathrm{EU}$ and non-EU countries, retrieved from a Eurobarometer survey, we conducted probit and IV probit regressions. These have tested the assumed relationship between higher education and entrepreneurial activities. Our results strongly suggest that higher education can often be very beneficial for starting up a new business and this seems to be one of the factors determining the success of new businesses. Furthermore, those respondents who attended courses related to entrepreneurship appear to be more active in starting-up a business and this seems to be also positively correlated with the company's future success. Interestingly, university graduates from Brazil, Portugal and India in particular, tend to appreciate the role that their universities have played in acquiring the skills to enable them to run a business.
\end{abstract}

Keywords: Entrepreneurship; Startups; Higher Education; Universities; Entrepreneurial Skills; Education.

\section{Introduction}

The share of population with tertiary education is growing rapidly in the EU and universities still produce high numbers of educated people, thus the employment of graduates becomes an issue in many countries (Nunez, Livanos, 2009). With respect to this, there is a growing discussion on the problem of potential overeducation reported for example by Mavromaras et al. (2013). In line with this fact, it is increasingly important to design higher education for the needs of the labor market. There is relatively strong evidence that a university degree may increase the chance of getting a job as an employee (for example Mincer, 1991; Ionescu, 2012). However, the effect of higher education on entrepreneurship, as arguably the most potent economic force (Kuratko, 2005), is not so obvious. On the one hand, most entrepreneurial activities do not require higher education qualifications, and the utilization of knowledge gained during university study in entrepreneurship may be doubtful. Moreover, those people who decided to study less could devote more time to starting own business. On the other hand, students may develop some kind of entrepreneurial attitude, acquire some important skills and make new contacts during the study. All of these could be beneficial for starting their own business. If education contributes to entrepreneurial success, entrepreneurs could benefit from further investment in the education.

Hence, our paper aims at examining the potential effect of higher education on the probability of starting a business as well as its further success. There are only a limited number of studies dealing with this problem (e.g. Wach \&
Wojciechowski, 2016; Turker \& Selcuk, 2009; Startiene \& Remeikiene, 2009). As far as we know the empirical analysis based on such a large sample has not been determined yet. Our study provides some new insight into this problem with the main focus on certain benefits that higher education could bring for entrepreneurs. We are focused not only on starting new businesses, but we also take into account a proxy variable for its potential success. The novelty of our research also lies in the use of factor analysis in order to capture a variable related to skills gained during education. In order to test the mentioned relationship we conduct probit and IV probit regression analysis. Our results are critically compared with the findings of previous research.

The analysis is based on the large dataset from all the EU countries as well as several non-EU countries. In the next section we review the literature dealing with our research topic. The third section will be devoted to a more detailed overview of the data and methodology used in the analysis. The most important results are summarized in the section four and conclusions are made in the final section of the paper.

\section{Literature Review}

The reduction of the risk of being unemployed is traditionally considered as one of the main benefits resulting from higher education (Mincer, 1991). As reported by Ionescu (2012), better education increases people's chances of employment as well as increases the probability of keeping a job during a crisis. Higher education helps to provide a skilled labor force and facilitates reaction to changing labor market demands in the current knowledge- 
based economy (Enders, 2010). The share of the adult population with tertiary education and intensity of R\&D could be considered as two of the most important factors having a positive effect on the growth of regional GDP in the EU (Sterlacchini, 2008; Badinger \& Tondl, 2003). The effect of higher education institutions on regional development is also potentially considerable, but the extent of potential benefits depends on the quality of a particular institution as well as in the setting of policy frameworks in the region (Arbo \& Benneworth, 2007).

The positive economic effect of higher education could be partially mediated through the impact on entrepreneurship. The scope and structure of entrepreneurial activity are strongly correlated with economic growth (Lekovic et al., 2014). Higher education institutions could influence entrepreneurial activities in the region in several ways. Universities or research organizations could create their own spin-off companies. Furthermore, there are also some companies founded by university graduates and employees located in a region (Strauf \& Scherer 2008). However, the potential impact of higher education on individual engagement in entrepreneurship is at first glance less evident.

According to the theoretical model developed by Lucas (1978) entrepreneurship is a function of heterogeneous entrepreneurial ability, with those individuals that have higher ability being more successful. Despite the fact that education was not directly associated with entrepreneurial ability in his model, this relationship is possible and it was further examined in more recent studies (such as Van Praag \& Cramer; 2001; Van der Sluis et al., 2008). On the one hand education improves individuals' abilities and knowledge, making them more aware about business opportunities and entrepreneurial processes. On the other hand, education is time demanding and also increases the chances of finding less risky wage employment and lowers interest in entrepreneurship (Daghbashyan \& Harsman, 2014). According to Duta et al. (2011) successful entrepreneurs have to identify the market opportunities which others fail to notice, and then exploit these opportunities in a timely and effective manner. This is where education could play an essential role, by providing them with appropriate knowledge and skills. Lee et al. (2005) argue that starting a business without the necessary knowledge is a high risk activity. It is obvious that a certain level of knowledge is often necessary for starting and maintaining any business. Thus, more years of education could be in general beneficial for entrepreneurial profitability (Kolstad \& Wiig, 2015). Furthermore, Robinson and Sexton (1994) found that the probability of becoming self-employed increased by $0.8 \%$ with each year of education. Similarly, they also argue that the income of self-employed people significantly increases with each year of education. In contrast, according to Van der Sluis et al. (2008) there is no significant effect of education on selection into entrepreneurship, but education has still some positive impact on entrepreneurs' performance with the return to a marginal year of schooling being $6.1 \%$.

With respect to higher education, Masakure (2012) based on a sample from Canada found that university education could have a positive effect on entrepreneurship, but some lower level of education reduces self-employment propensity. According to the results, the probability of becoming self-employed increases by $0.8 \%$ for each year of formal education. Moreover, higher education seems to be a factor positively influencing the willingness of unemployed people to start own business (Startiene \& Remeikiene, 2009). The initial motivation for starting a business appears to be different for those with higher education. University graduates perceive their business more often as a mission, whereas the entrepreneurs without a university degree are often forced to start their own business due to lack of employment opportunities (Bartos et al., 2015). According to the results of Turker and Selcuk, (2009) a supportive university environment is one of the key factors affecting the possibility of choosing an entrepreneurial career. If a university ensures adequate knowledge and motivates students for entrepreneurship, the possibility of choosing this as a career might increase.

Higher education could have also differing influences on entrepreneurship across ethnic groups (Thompson et al., 2010) as well as across fields of study. Daghbashya and Harsman (2014) argue that graduates from the most prestigious universities with degrees in the social, natural and medical sciences, as well as those educated as teachers, are on average more interested in entrepreneurial occupations compared to other graduates.

In recent years there are more universities involved in entrepreneurship education (Kuratko, 2005). The effect of this specific type of higher education on entrepreneurship activities has been to some extent examined by several studies. As found by Rantanen et al. (2015) entrepreneurship education is very important factor supporting further entrepreneurship of young people. On the other hand, Nabi et al. (2016) examines the role of learning and inspiration in developing students' entrepreneurial intentions at British universities. The analysis is focused especially on the effects of students' partition in entrepreneurship education. They found that the potential effect of entrepreneurship education is in fact mixed and in some cases could even lead to a loss of entrepreneurial intentions. Ling and Venesaar (2015) conclude that the traditional teaching methods based on memorizing facts are still often used in entrepreneurship education, which creates a significant obstacle for students to gain necessary practical skills. On the other hand, Peterman and Kennedy (2003) argue that participation in entrepreneurship education positively influence students' perceptions of entrepreneurship.

There are of course several other important factors besides education, which appear to have an effect on the individual decision to start a business as well as its further success. The choice of professional career is the result of subjective intention. Intensions in general could be with a relatively high degree of accuracy predicted by personal attitudes towards the behaviour, subjective norms and perceived control over the behaviour (Ajzen, 1991). Ajzen's theory has been successfully verified based on the example of entrepreneurial intentions of Polish students by Wach and Wojciechowski (2016). They found that entrepreneurial intentions of students are determined by their attitude toward entrepreneurship, subjective norms, perceived behavioural control and risk attitude. They also conclude that tertiary education has a role in shaping the entrepreneurial mindset of students. 
With respect to socio-economic characteristics several authors have found that gender could be an important factor with the effect on the entrepreneurial intention (Wang \& Wong, 2004; Minniti \& Nardone, 2007; Startiene \& Remeikiene, 2009). Other key variables often mentioned in the literature are age (Gupta \& York, 2008; Levesque \& Minniti, 2006) and previous labor experience (Cooper and Park, 2008). Furthermore, the previous experience with entrepreneurship in the immediate family could also significantly increase the probability of starting a business (Wang \& Wong, 2004; Matthews \& Moser 1996; Startiene \& Remeikiene, 2009; Kuttim et al., 2014). There are also several other important external factors such as for example the business environment in the country and financial support from government (Naser et al., 2009). However, individual wealth (Evans \& Jovanovic, 1989) and access to capital (Elston \& Audretsch; 2011) are also often considered as the essential issues when starting new business.

\section{Data and Methodology}

The main aim of our paper is to examine the potential effect of higher education on the probability of starting a business as well as its further success. In line with the main aim we specified 4 main research questions:

- Research question 1: Are people with tertiary education more likely to start their own business?

- Research question 2: Are people with tertiary education more successful in maintaining the business for a longer period of time?

- Research question 3: Are people that have entrepreneurial courses or activity during education more likely to start their own business?

- Research question 4: Have skills and knowledge gained due to education positive impact on the probability of starting a business and its further durability?

In order to test this relationship we applied probit regression analysis. We also decided to use IV probit regression for robustness check of previous results. This approach should reduce the potential risk of endogeneity. Furthermore, dummy variables for each country except one have been also included into all probit regressions. We used the data from flash Eurobarometer 354 (2013) survey in our analysis. The survey was conducted from June to August 2012 in the EU member states and several non-EU states. The geographic coverage of the survey was as follow: Austria (AT); Belgium (BE); Bulgaria (BG); Brazil (BR); Switzerland (CH); China (CN), Cyprus (CY); Czech Republic (CZ); Germany (DE); Denmark (DK); Estonia (EE); Spain (ES); Finland (FI); France (FR); United Kingdom (GB); Greece (GR); Croatia (HR); Hungary (HU); Ireland (IE); India (IN); Iceland (IS); Israel (IL), Italy (IT); Japan (JP); Korea, Republic of (KR); Lithuania (LT); Luxembourg (LU); Latvia (LV); Malta (MT); Netherlands (NE); Norway (NO); Poland (PL); Portugal (PT); Romania (RO); Russian Federation (RU); Sweden (SE); Slovenia (SI); Slovakia (SK); Turkey (TR); United States (US).

Together 42080 respondents participated in this survey. The average age of respondents is 47.9 years with standard deviation of 17.7 years. However, in most of the regressions the sample has been restricted to respondents with an age over 25 or 30 years. This has been performed to maintain comparable results for less educated respondents and those with higher education, who ended their full-time education later and they are less likely to have started own business during their study. Approximately $57 \%$ of respondents are males and $43 \%$ are females.

The description as well as the coding of all variables can be found in the Appendix. We use two dependent variables and several independent variables. The first dependent variable indicates whether respondents have ever started any business. It is in fact a dummy variable based on the answers to the question whether respondents ever started or taken over a business. Those who started or took over any business have been coded as 1 and the others have been coded as 0 . The second dependent variable deals not only with starting-up a business, but also with its duration. It is based on the answers to questions about the current situation of the respondent. Those respondents who answered that they have started or taken over a business in the past which is still operating today were coded as 1 . Everyone else was coded as 0 in this variable. We referred to this variable as "Starting a successful business". Despite the fact, that the actual duration of the business may in fact vary, that business that failed or was sold in the past has been always coded as 0 .

The main independent variable with respect to this paper is the education of the respondent. Respondents were asked how old they had been when they stopped their full-time education. This is a very good proxy for the respondents' educational level.

This variable has also been used in a quadratic form in some regressions. In the analysis we also often distinguished between higher education and other education. In order to more determine respondents with higher education, we decided to divide the sample into two groups. Those respondents that finished full-time education later than at the age of 20 have been identified as those with a higher education and have been coded as 1 . Those that finished education earlier were coded as 0 for this variable. Secondary level of education is normally completed in the age from 17 to 19 in all countries in the sample. Most commonly graduates from secondary level of education are 18 years old. Hence, when setting the age for higher education we have also taken into account potential repeating of one or two years or any form of continuing education for the same period of time.

We also used variables regarding respondents' views on the potential benefits with respect to entrepreneurship arising from their education (see Figure 1).

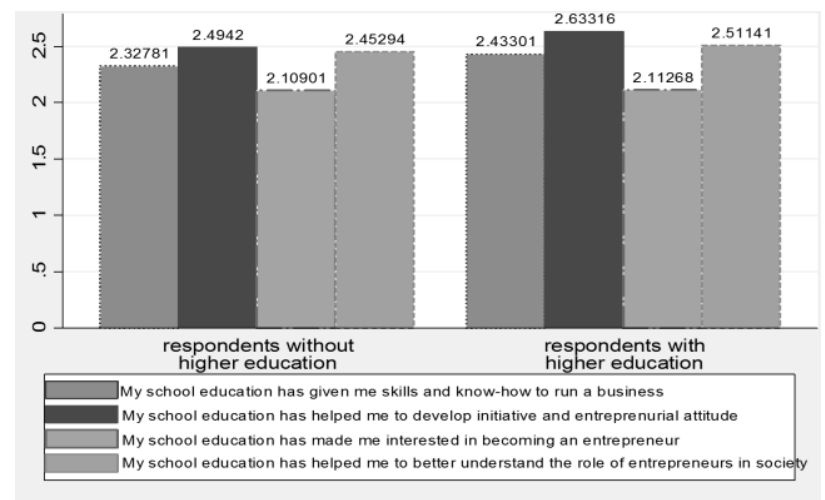

Figure 1. Respondents' Views on the Benefits of School Education on Potential Entrepreneurial Activities

Source: Authors' calculation based on data from flash Eurobarometer 354 (2013). 
Furthermore, these four variables have been used as input into factor analysis. The results of the factor analysis, allowed us to identify one factor, which is the unobserved (latent) variable that captures most of the overall variance in all four variables. This procedure allows us to use the first factor as an independent variable capturing overall skills, knowledge and entrepreneurial attitude gained due to education. According to the calculations of the eigenvalues (values over one) only the first factor (Factor 1) should be used, as we can see in the scree plot in Figure 2. The factor loadings and the composition of factor 1 , can be seen in Table 1 .

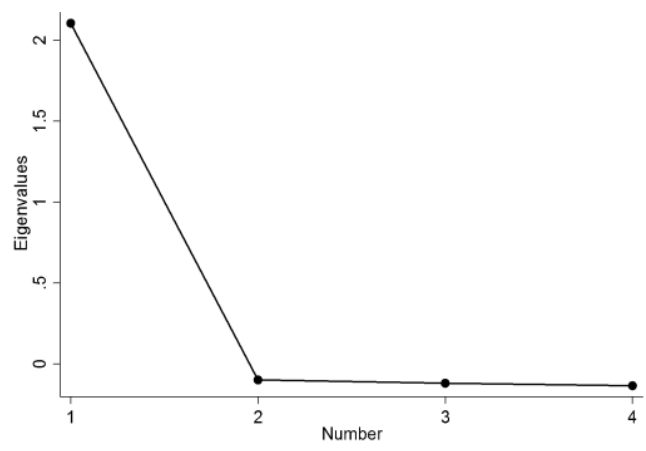

Figure 2. Scree Plot of Eigenvalues Source: Authors' calculation.

Table 1

Factor Loadings and Scoring Coefficients for Factor 1

\begin{tabular}{|l|c|c|c|}
\hline \multicolumn{1}{|c|}{ Variables } & $\begin{array}{c}\text { Factor 1 } \\
\text { loadings }\end{array}$ & Uniqueness & $\begin{array}{c}\text { Scoring } \\
\text { coefficients }\end{array}$ \\
\hline Entrepreneurial attitude & 0.7429 & 0.4481 & 0.2365 \\
\hline Understand the role & 0.7415 & 0.4501 & 0.2914 \\
\hline Skills and know-how & 0.7249 & 0.4745 & 0.2703 \\
\hline $\begin{array}{l}\text { Interested in becoming } \\
\text { entrepreneur }\end{array}$ & 0.6908 & 0.5228 & 0.2896 \\
\hline
\end{tabular}

Source: Authors' calculation.

Moreover, we also conducted instrumental variables (IV) regressions, where we applied the instrumental variable about taking a course or some activity related to entrepreneurship at school and university. This has been applied in order to reduce the risk of potential endogeneity.

We assume that the effect of mentioned skills and knowledge on entrepreneurial activities is directly intermediated through the course or activity at school or university. Furthermore, having a course or activity about entrepreneurship is highly correlated with the development of entrepreneurial skills and knowledge at school or university. Besides the variables related to education, we also used several control variables in the regressions. These variables are in particular socio-economic indicators such as age, gender, number of household members and place of residence. Moreover, we also take into account whether the parents of the respondent have any experience with entrepreneurship. We assume that this kind of family experience could be an important factor in respect to starting up a business by the respondent. In the next section we present and discuss the most important results of our analysis.

\section{Results}

Firstly, it is important to mention that there are some cross-country differences in potential business benefits arising from education. The difference in entrepreneurial skills and know-how gained in education are evident also when examined among the countries included in our sample. In this case we focus our attention only on the respondents with higher education. As it can be seen in Figure 3, especially higher education institutions from Brazil, Croatia and Portugal appear to be the leaders in providing education that is useful for entrepreneurship.

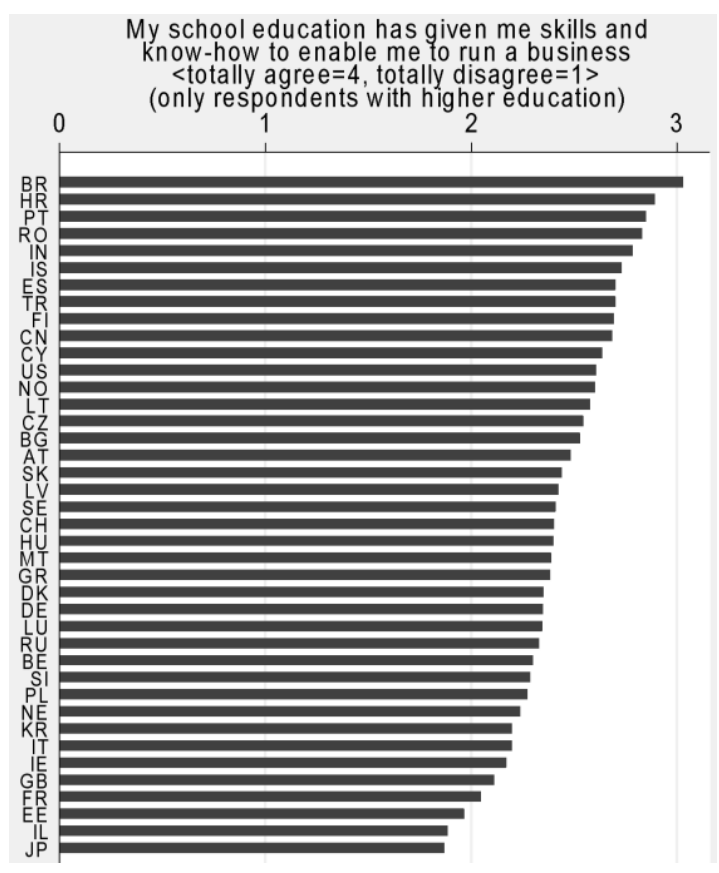

Figure 3 Skills and Know-How for Running own Business gained due to Education in Selected Countries

Source: Authors based on data from flash Eurobarometer 354 (2013).

In line with our main aim, we further focus our analysis on the potential relationship between higher education and the probability of starting a business. As can be seen in Figure 4., those that have higher education seem to be more active in starting a business compared to those with lower education. Moreover, those who took the course or were involved in an activity related to entrepreneurship are slightly more often engaged in starting up a business as well. The difference between respondents with different educational levels is even more significant. Thus, the results suggest that those with higher education who took during their study a course on entrepreneurship had the highest probability of starting a business.

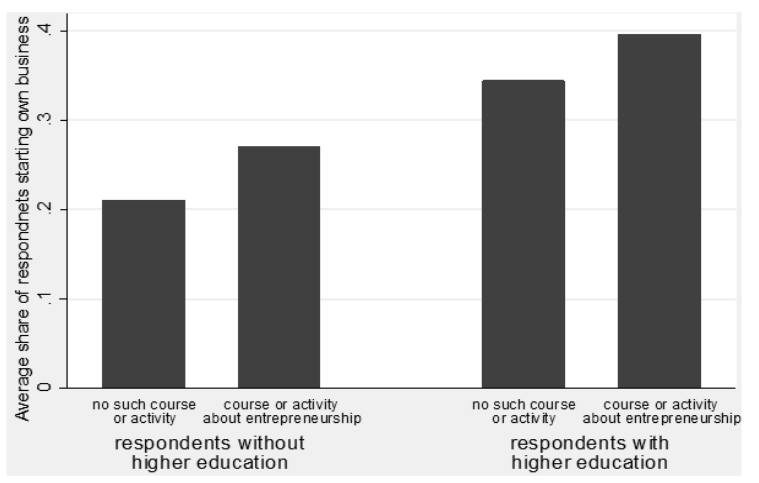

Figure 4. Average Shares of Respondents Starting Own Business for Different Educational Level and Engagement in School Course or Activity About Entrepreneurship

Source: Authors based on data from flash Eurobarometer 354 (2013). 
Despite the fact, that the probability of starting a new business is important, the success of the business is probably even more important. We identified the successful business with those that were still operating at the time of the survey.

As we can see in Figure 5, the majority of respondents that started a successful business have higher education. The difference between both groups is even more significant than in the previous case.

It seems to be likely that people with higher education are not only more active in starting a business, but they are also often more successful in running their business. The potential benefit from taking a course on entrepreneurship seems to be almost negligible for the group with higher education. However, this course or activity does appears to be beneficial for less educated respondents.

The potential effect of higher education on the probability of starting a business has been further examined by probit regression analysis. The results or regressions are summarized in Table 2. Besides the above mentioned control variables we also applied dummy variables for each country represented in the sample (except one) in order to capture country specific fixed effects.

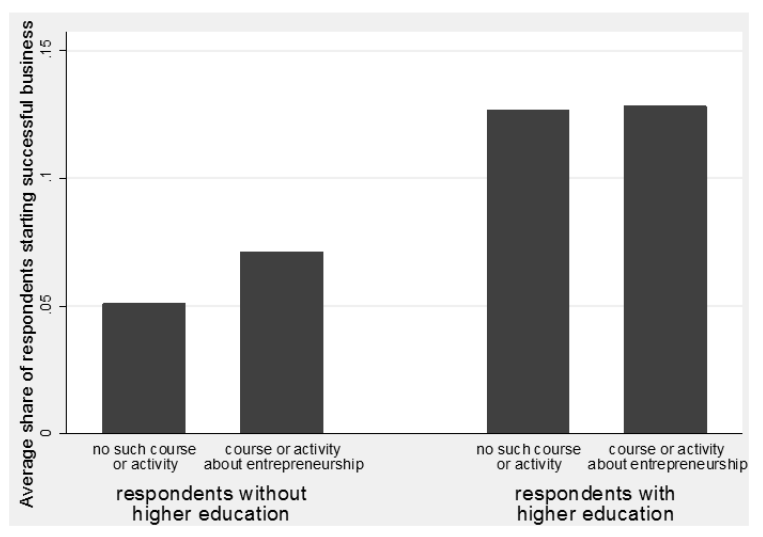

Figure 5. Average Shares of Respondents Starting Successful Business (i.e. Still Operating) for Different Educational Levels and Engagement in School Courses or Activities about Entrepreneurship

Source: Authors based on data from flash Eurobarometer 354 (2013).

Table 2

The Results of Probit Regression Analysis With "Start a Business' as the Dependent Variable

\begin{tabular}{|c|c|c|c|c|}
\hline \multicolumn{5}{|c|}{$\begin{array}{l}\text { Dependent variable: Start a business } \\
\text { (Coding: Yes = 1; No or DK = 0) }\end{array}$} \\
\hline & $\begin{array}{c}(1) \\
(\mathbf{d y} / \mathbf{d x})\end{array}$ & $\begin{array}{c}(2) \\
(d y / d x)\end{array}$ & $\begin{array}{c}(3) \\
(d y / d x)\end{array}$ & $\begin{array}{c}(4) \\
(d y / d x)\end{array}$ \\
\hline Higher education & $\begin{array}{l}0.0335 * * * \\
(5.98)\end{array}$ & $\begin{array}{l}0.1249 * * * \\
(7.48)\end{array}$ & & \\
\hline Education & & & $\begin{array}{l}0.0293^{* * * *} \\
(4.20)\end{array}$ & \\
\hline \begin{tabular}{|l}
$\begin{array}{l}\text { Education }^{2} \\
\text { (squared) }\end{array}$ \\
\end{tabular} & & & $\begin{array}{l}-0.0006^{* * * *} \\
(-3.68)\end{array}$ & \\
\hline Attended school course or activity & & & & $\begin{array}{l}0.127 * * * \\
(21.53)\end{array}$ \\
\hline Age & $\begin{array}{l}0.0146^{* * * *} \\
(11.19)\end{array}$ & $\begin{array}{l}0.0116^{* * * *} \\
(7.51)\end{array}$ & $\begin{array}{l}0.0146^{* * * *} \\
(11.21)\end{array}$ & $\begin{array}{l}0.0226^{* * * *} \\
(11.74)\end{array}$ \\
\hline \begin{tabular}{|l|}
$\begin{array}{l}\text { ge }^{2} \\
\text { (squared) }\end{array}$ \\
\end{tabular} & $\begin{array}{l}-0.0001 * * * \\
(-11.64)\end{array}$ & $\begin{array}{l}-0.0001 * * * \\
(-8.36)\end{array}$ & $\begin{array}{l}-0.0001 * * * \\
(-11.64)\end{array}$ & $\begin{array}{l}-0.0002 * * * \\
(-11.93)\end{array}$ \\
\hline Gender & $\begin{array}{l}0.1747^{* * *} \\
(31.93)\end{array}$ & $\begin{array}{l}0.1738^{* * * *} \\
(32.24)\end{array}$ & $\begin{array}{l}0.1739 * * * \\
(31.70)\end{array}$ & $\begin{array}{l}0.1764 * * * \\
(31.26)\end{array}$ \\
\hline Household members & $\begin{array}{l}0.0101 * * * \\
(3.49)\end{array}$ & $\begin{array}{l}0.0113 * * * \\
(4.77)\end{array}$ & $\begin{array}{l}0.001 * * * \\
(4.18)\end{array}$ & $\begin{array}{l}0.1574 * * * \\
(3.99)\end{array}$ \\
\hline Village & $\begin{array}{l}0.0281 * * * \\
(3.99)\end{array}$ & $\begin{array}{l}0.2852 * * * \\
(4.19)\end{array}$ & $\begin{array}{l}0.0286^{* * * *} \\
(4.04)\end{array}$ & $\begin{array}{l}0.0429 * * * \\
(4.42)\end{array}$ \\
\hline City & $\begin{array}{l}0.0074 \\
(1.13)\end{array}$ & $\begin{array}{l}0.0048 \\
(0.74)\end{array}$ & $\begin{array}{l}0.0072 \\
(1.08)\end{array}$ & $\begin{array}{l}0.0243 \\
(1.37)\end{array}$ \\
\hline \begin{tabular}{|l}
$\begin{array}{l}\text { Parents } \\
\text { self-employed }\end{array}$ \\
\end{tabular} & $\begin{array}{l}0.1165^{* * * *} \\
(17.85)\end{array}$ & $\begin{array}{l}0.1105^{* * * *} \\
(17.24)\end{array}$ & $\begin{array}{l}0.1170 * * * \\
(17.86)\end{array}$ & $\begin{array}{l}0.1028 * * * \\
(17.44)\end{array}$ \\
\hline Dummy variables (countries) & Included & Included & Included & Included \\
\hline Sample restriction & $\begin{array}{l}\text { Age }>25 \& 15< \\
\text { Education }>35\end{array}$ & $\begin{array}{l}\text { Age }>20 \& 12< \\
\text { Education }>35\end{array}$ & $\begin{array}{l}\text { Age }>25 \& 15< \\
\text { Education }>35\end{array}$ & $\begin{array}{l}\text { Age }>25 \& 15< \\
\text { Education }>35\end{array}$ \\
\hline Education - turning point (age) & & & 26.1 years & \\
\hline Obs. & 29335 & 30051 & 29335 & 29335 \\
\hline Wald $X^{2}$ & 2239.46 & 2292.67 & 2154.1 & 2551.6 \\
\hline Log pseudo-likelihood & -17454.7 & -16704.0 & -16521.9 & -16308.8 \\
\hline Pseudo $\mathrm{R}^{2}$ & 0.066 & 0.069 & 0.066 & 0.078 \\
\hline
\end{tabular}

Source: Authors' calculation based on data from flash Eurobarometer 354 (2013).

Note: (.) denotes z-statistics and $* * * * * *$ denotes statistically significant at the 5/1 percent level. Standard errors have been corrected for heteroscedasticity.

The results of probit regression strongly suggest that people with higher education tend to be more often engaged in starting a business. All three variables related to education are statistically significant at the $1 \%$ level and all of them have positive coefficients. The results are partially in line for example with Robinson and Sexton (1994) who found that the probability of becoming self-employed is increasing with each year of education. However, in our case the potential effect of education in general seems to be non-linear. We have found an inverse U-shaped relationship between respondent's age when they finished full-time education and the probability of starting a business. However, the estimated turning point is beyond 26 years, which means that the probability of starting a business decreases only for those who 
study longer than the standard period of university studies. These are mostly $\mathrm{PhD}$ students who are more focused on research and they are perhaps less involved in entrepreneurial activities. In general, we can say that higher education seems to be positively correlated with probability of starting up a business. The same is true for attending a school course on entrepreneurship or for being engaged in an activity related entrepreneurship. We found that those respondents who attend such a course or activity are significantly more likely to start a business as well as to start a successful business. Mentioned activities could be mostly associated with entrepreneurship education. These results are in line with findings of Rantanen et al. (2015). The entrepreneurial courses or entrepreneurial education in general seems to be important tool for increasing entrepreneurial intentions among students. This is also complementary with the argument of Peterman and Kennedy (2003).

With respect to the control variables, most of them are statistically significant at the $1 \%$ level. Those respondents whose parents have previous experience with self-employment are significantly more active in starting-up their own business. The potential relationship between a respondent's age and the probability of starting a new business appears to have an inverse U-shape. Men also tend to more often start their own business compared to women. This seems to be very significant factor, which is complementary with several previous studies such as for example Wang and Wong (2004) or Minniti and Nardone (2007). It could be partially related to risk perception and in general less risk-averse behavior of women.

We also get similar results for those living in households with more members. This could be perhaps related to a family business and the support of other family members. Furthermore, those respondents who are living in a village are also more often involved in founding a business. On the other hand, it seems likely that living in a city does not have any significant effect on the entrepreneurial activity compared to living in a smaller town. Thus, we can say that rural environment could increase the probability of starting a business but do not have effect on its further success.

In the next step of our analysis, we swapped the dependent variable for starting up a successful business, which in our case means that this business is still operating. This could be for us even more important than the fact of starting any business. The results of the probit analysis with this dependent variable are shown in Table 3 . These results are in some respect rather similar to those from the previous regressions. Respondents with higher education are more often involved in starting-up a successful business compared to those with lower educational level. The effect of the respondent's age when they finished education appears to be again non-linear and the turning point has in this case shifted even later (nearly at 30 years). Hence, this could mean that full-time education, even after the age of 25 could be still beneficial for the potential success of a business.

Attending a school course or participation or activity on entrepreneurship appears to be positively correlated with the success of the business. Moreover, all the variables related to skills, knowledge and attitude to entrepreneurship gains during the education are statistically significant at the $1 \%$ level. Those respondents who developed entrepreneurial skills during their education are more likely to start a business which is going to last for a longer time. The impact of this variable seems to be the greatest from all three variables related to the potential benefits of education.

The results with respect to the control variables are again similar to previous regressions. The probability of starting a successful business appears to be decreasing with the respondents' age and increasing in the number of household members. The same is true for men and for those whose parents have some previous experience with entrepreneurship. The previous experience with entrepreneurship within the close family have been also found as very important factor in several other studies such as Wang and Wong (2004), Matthews and Moser (1996) or Kuttim et al. (2014).

Furthermore, there is some weaker evidence from some regressions that respondents who live in the cities could be somewhat more successful in starting and maintaining their own business. Attending a school course on entrepreneurship seems to be, together with gender the most important factors with a potential effect on starting-up a successful business. However, the interpretation of our results as direct causal links is to some extent limited due to the potential problem of endogeneity. Despite the fact that reverse causality does not seem to be an important issue in our case, there could be some unobserved variables such as initial skills or selfmotivation which might pose some problems.

Table 3

The Results of Probit Regression Analysis with "Start a Successful Business" as the Dependent Variable

\begin{tabular}{|c|c|c|c|c|c|c|}
\hline \multicolumn{7}{|c|}{ Dependent variable: Start a successful business (coding: $Y E S=1$; $N O$ or $D K=0$ ) } \\
\hline & (1) $(d y / d x)$ & $(2)(d y / d x)$ & (3) $(d y / d x)$ & (4) $(d y / d x)$ & $(5)(d y / d x)$ & (6) $(d y / d x)$ \\
\hline Higher Education & $\begin{array}{l}0.0140 * * * \\
(5.15)\end{array}$ & & & & & \\
\hline Education & & $\begin{array}{c}0.0095 * * * \\
(4.07)\end{array}$ & & & & \\
\hline $\begin{array}{l}\text { Education }^{2} \\
\text { (squared value) }\end{array}$ & & $\begin{array}{c}-0.0002 * * * \\
(-3.19)\end{array}$ & & & & \\
\hline Attended school course or activity & & & $\begin{array}{c}0.0372 * * * \\
(12.63)\end{array}$ & & & \\
\hline Developed entrepreneurial skills & & & & $\begin{array}{c}0.0108 * * * \\
(10.02)\end{array}$ & & \\
\hline Developed entrepreneurial attitude & & & & & $\begin{array}{c}0.0101 * * * \\
(8.90)\end{array}$ & \\
\hline $\begin{array}{l}\text { Understood the role of entrepreneurs in } \\
\text { society }\end{array}$ & & & & & & $\begin{array}{c}0.0058 * * * \\
(5.30)\end{array}$ \\
\hline Age & $\begin{array}{c}-0.0026 * * * \\
(-27.19)\end{array}$ & $\begin{array}{c}-0.0023 * * * \\
(-24.34)\end{array}$ & $\begin{array}{c}-0.0023 * * * \\
(-24.83)\end{array}$ & $\begin{array}{c}-0.0025 * * * \\
(-25.57)\end{array}$ & $\begin{array}{c}-0.0025^{* * *} \\
(-25.56)\end{array}$ & $\begin{array}{c}-0.0025^{* * * *} \\
(-25.31)\end{array}$ \\
\hline Gender & $\begin{array}{c}0.0381 * * * \\
(14.08)\end{array}$ & $\begin{array}{c}0.0299 * * * \\
(12.59)\end{array}$ & $\begin{array}{l}0.0299 * * * \\
(12.65)\end{array}$ & $\begin{array}{l}0.0295^{* * * *} \\
(23.08)\end{array}$ & $\begin{array}{c}0.0302 * * * \\
(1.28)\end{array}$ & $\begin{array}{c}0.0314 * * * \\
(12.63)\end{array}$ \\
\hline
\end{tabular}




\begin{tabular}{|c|c|c|c|c|c|c|}
\hline \multicolumn{7}{|c|}{ Dependent variable: Start a successful business (coding: YES=1; NO or DK=0) } \\
\hline & (1) $(\mathrm{dy} / \mathrm{dx})$ & (2) $(\mathrm{dy} / \mathrm{dx})$ & (3) $(\mathrm{dy} / \mathrm{dx})$ & (4) $(d y / d x)$ & (5) $(\mathrm{dy} / \mathrm{dx})$ & (6) $(\mathrm{dy} / \mathrm{dx})$ \\
\hline Household members & $\begin{array}{c}0.0047 * * * \\
(4.42)\end{array}$ & $\begin{array}{l}0.0047 * * * \\
(5.11)\end{array}$ & $\begin{array}{c}0.0043 * * * \\
(4.71)\end{array}$ & $\begin{array}{l}0.0031 * * * \\
(3.21)\end{array}$ & $\begin{array}{l}0.0029 * * * \\
(2.96)\end{array}$ & $\begin{array}{l}0.0031 * * * \\
(3.08)\end{array}$ \\
\hline Village & $\begin{array}{l}0.0017 \\
(0.50)\end{array}$ & $\begin{array}{l}0.0022 \\
(0.73)\end{array}$ & $\begin{array}{l}0.0017 \\
(0.59)\end{array}$ & $\begin{array}{c}-0.0008 \\
(-0.28)\end{array}$ & $\begin{array}{c}0.0002 \\
(0.06)\end{array}$ & $\begin{array}{c}0.0003 \\
(0.08)\end{array}$ \\
\hline City & $\begin{array}{c}0.0089 * * * \\
(2.83)\end{array}$ & $\begin{array}{l}0.0062 \\
(0.74)\end{array}$ & $\begin{array}{l}0.0071^{* *} \\
(2.57)\end{array}$ & $\begin{array}{c}0.0033 \\
(1.14)\end{array}$ & $\begin{array}{c}0.0031 \\
(1.06)\end{array}$ & $\begin{array}{c}0.0033 \\
(1.12)\end{array}$ \\
\hline Parents self-employed & $\begin{array}{l}0.0199 * * * \\
(6.34)\end{array}$ & $\begin{array}{l}0.0156^{* * *} \\
(5.66)\end{array}$ & $\begin{array}{l}0.0151 * * * \\
(5.55)\end{array}$ & $\begin{array}{l}0.0168 * * * \\
(5.83)\end{array}$ & $\begin{array}{l}0.0170 * * * \\
(5.84)\end{array}$ & $\begin{array}{l}0.0179 * * * \\
(6.07)\end{array}$ \\
\hline $\begin{array}{l}\text { Dummy variables for each country } \\
\text { (except one country) }\end{array}$ & Included & Included & Included & Included & Included & Included \\
\hline Sample restriction & $\begin{array}{c}\text { Age }>25 \& \\
15<\text { Education } \\
>35\end{array}$ & $\begin{array}{c}\text { Age }>30 \& \\
12<\text { Education }> \\
35 \\
\end{array}$ & \begin{tabular}{|c|} 
Age $>30 \&$ \\
$12<$ Education $>3$ \\
5
\end{tabular} & $\begin{array}{c}\text { Age }>30 \& \\
12<\text { Education }>3 \\
5 \\
\end{array}$ & $\begin{array}{c}\text { Age }>30 \& \\
12<\text { Education }>3 \\
5\end{array}$ & $\begin{array}{c}\text { Age }>30 \& \\
12<\text { Education }>35\end{array}$ \\
\hline $\begin{array}{l}\text { Education } \\
\text { (finished at age) - turning point }\end{array}$ & & 29.74 Years & & & & \\
\hline Observations & 29335 & 30051 & 30051 & 29220 & 29091 & 28994 \\
\hline Wald X ${ }^{2}$ & 1289.75 & 1166.1 & 1259.621 & 1276.1 & 1245.12 & 1195.84 \\
\hline Log Pseudolikelihood & -6976.4 & -6224.5 & -6180.0 & -6089.13 & -6096.37 & -6090.60 \\
\hline Pseudo $\mathrm{R}^{2}$ & 0.093 & 0.095 & 0.102 & 0.103 & 0.100 & 0.097 \\
\hline
\end{tabular}

Source: Authors' calculation based on data from flash Eurobarometer 354 (2013).

Notes: (.) denotes z-statistics and */**/*** denotes statistically significant at the 10/5/1 percent level. Standard errors have been corrected for heteroscedasticity.

There could be a problem of the possible endogeneity of the schooling decision (Glewwe, 1999) and unobserved heterogeneity, such as initial skills and motivation, which may affect the measured effect of education on the probability of entry into an entrepreneurial position and subsequent performance (Sluis et al., 2005). In order to deal with this potential problem we decided to apply instrumental variables (IV) regression. The main independent variable in this case is Factor 1 which we get from factor analysis of the four variables related to skills, attitudes and knowledge gain due to the education. Perhaps, we can argue that this variable could be affected by the endogeneity problem, which we want to eliminate. First of all, using the factor analysis in order to identify this variable allow us to capture some unobserved latent factors. Secondly, this variable has been instrumented. The attendance of a course or an activity related to entrepreneurship was selected as the best available instrument for this variable. The results of IV regressions are shown in Table 4.

Table 4

The Results of IV Regressions With "Factor 1" As the Main Independent Variable

\begin{tabular}{|c|c|c|}
\hline Dependent variable: & Start a business & Start a successful business \\
\hline & (1) (dy/dx) & (2) $(\mathrm{dy} / \mathrm{dx})$ \\
\hline $\begin{array}{l}\text { Factor 1: Skills \& knowledge gained due to education } \\
\text { (Instrumented) }\end{array}$ & $\begin{array}{l}0.656 * * * \\
(27.07)\end{array}$ & $\begin{array}{l}0.546 * * * \\
(15.13)\end{array}$ \\
\hline Age & $\begin{array}{l}-0.003 * * * \\
(-5.76)\end{array}$ & $\begin{array}{l}-0.024 * * * \\
(-28.82)\end{array}$ \\
\hline Gender & $\begin{array}{l}0.376^{* * * *} \\
(21.93)\end{array}$ & $\begin{array}{l}0.233 * * * \\
(9.91) \\
\end{array}$ \\
\hline Household members & $\begin{array}{l}0.004 * * \\
(2.57)\end{array}$ & $\begin{array}{l}0.002 \\
(1.01)\end{array}$ \\
\hline Village & $\begin{array}{l}0.089 * * * \\
(4.53)\end{array}$ & $\begin{array}{l}0.014 \\
(0.50)\end{array}$ \\
\hline City & $\begin{array}{l}0.038 * * \\
(2.06)\end{array}$ & $\begin{array}{l}0.051^{*} \\
(1.89)\end{array}$ \\
\hline $\begin{array}{l}\text { Parents } \\
\text { self-employed }\end{array}$ & $\begin{array}{l}0.224 * * * \\
(12.19)\end{array}$ & $\begin{array}{l}0.130^{* * * *} \\
(5.05)\end{array}$ \\
\hline Instrument: & Attended school course or activity & Attended school course or activity \\
\hline Dummy variables for 39 countries: & Included & Included \\
\hline Sample restriction & Age $>25 \&$ Education $>14$ & Age $>25 \&$ Education $>14$ \\
\hline Observations & 30715 & 30715 \\
\hline Wald $\mathrm{X}^{2}$ & 3519.87 & 2105.27 \\
\hline Log pseudolikelihood & -54321.7 & -44114.24 \\
\hline
\end{tabular}

Source: Authors' calculation based on data from flash Eurobarometer 354 (2013).

Note: (.) denotes z-statistics and $* * * * * *$ denotes statistically significant at the 5/1 percent level. Standard errors have been corrected for heteroscedasticity

As it can be seen in the table, the factor variable appears to be significant at the $1 \%$ level. It is also the variable with the most intensive effect on both starting a business as well as starting a successful business.

The results of the IV regression strongly suggest that the skills and knowledge gained due to education is one of the key factors positively affecting the probability of starting. This factor has also a strong positive effect on maintaining a business. The potential effects of control variables are again very similar to previous regressions and could be also seen as robustness checks.

We can summarize our results with respect to our four main research question:

- Research question 1: Based on our results we can conclude people with tertiary education seem to be more likely to start their own business. 
- Research question 2: Based on our results we can say people with tertiary education seem to be more successful in maintaining it for longer period of time.

- Research question 3: Our results suggest that people who attended some entrepreneurial courses or activities during education are more likely to start their own business.

- Research question 4: The results strongly suggest that skills and knowledge gained due to education have positive effect on the probability of starting their own business as well as on its durability.

Furthermore, our results also suggest that there are several other important factors beside higher education such as gender, age and previous experience of parents with entrepreneurship. These results are fully in accordance with the results of previous studied such as Wang and Wong (2004), Startiene and Remeikiene (2009), Gupta and York (2008), Levesque and Minniti (2006) and Matthews and Moser (1996).

At this point, we consider it appropriate to mention some limits to our research. First of all, the problems of the possible endogeneity and unobserved heterogeneity, such as initial skills and motivation, may affect the results despite our best efforts to eliminate them by using appropriate methodology and data. Nevertheless, the IV regression which we used is in our case the most suitable way to some extent deal with the mentioned problems.

Moreover, the selection of control variables has been in our case significantly limited by the availability of secondary data. We believe that the most important socioeconomic variables have been applied in the models, but it could be also useful to control for several others such as initial wealth of respondent before starting a business, initial skills and motivation or previous job experience.

\section{Conclusions}

Examining entrepreneurial activities and its effective support is a very important issue, due to the fact that entrepreneurship is considered as the most potent economic force (Kuratko, 2005). According to our results, higher education seems to be one of the possible ways how this impact could be achieved.

Despite the fact, that higher education is time demanding and increases the chances of finding a less risky wage job our results strongly suggest that higher education is positively correlated with entrepreneurial activities. People with higher education tend to be more active in starting their own business. Furthermore, this potential positive effect of higher education is even more important for starting up a successful business, which operates for a longer time.

We found that those respondents who attend a course or activity devoted to entrepreneurship are more likely to start a business as well as to start a successful business. Thus, we can say that supporting entrepreneurship education or any useful activities related to entrepreneurship during standard higher education could be very beneficial for increasing entrepreneurial activities in the economy. Especially important is the acquisition of certain skills and knowledge as well as developing an entrepreneurial attitude during their studies, which appears to be very significant with respect to starting a new business.

\section{Appendix}

Description and Coding of Variables used in Regressions

\begin{tabular}{|c|c|c|}
\hline Variable & Description of question & Coding \\
\hline \multicolumn{3}{|l|}{ Dependent variables: } \\
\hline Start a business & $\begin{array}{l}\text { Have you ever started a business, taken over } \\
\text { one? }\end{array}$ & $\begin{array}{l}\text { Yes, I started/took over a business }=1 \\
\text { No or DK }=0\end{array}$ \\
\hline Start a successful business & How would you describe your situation? & $\begin{array}{l}\text { You have started or taken over a business } \\
\text { which is still operating today }=1 \text {, Other } \\
\text { answers }=0 \text { (no longer operating...) }\end{array}$ \\
\hline \multicolumn{3}{|l|}{ Independent variables: } \\
\hline Education & How old were you when you stopped full-time education? & Exact age \\
\hline Education $^{2}$ & The squared value of age when respondent stopped full-time education. & \\
\hline Higher education & How old were you when you stopped full-time education? & $\begin{array}{l}\text { If more than } 20=1 \\
\text { If less than } 20=0\end{array}$ \\
\hline Attended school course & $\begin{array}{l}\text { At school or university, have you ever taken part in any course or activity about } \\
\text { entrepreneurship - that is turning ideas into action, developing own projects? }\end{array}$ & $\begin{array}{l}\text { YES }=1 \\
\text { NO or Don't know }=0\end{array}$ \\
\hline Age & How old are you? & Exact age \\
\hline $\mathrm{Age}^{2}$ & Squared value of respondents' age & \\
\hline Gender & Gender of respondent & Male $=1 ;$ Female $=0$ \\
\hline Household members & $\begin{array}{l}\text { Could you tell me how many people aged } 15 \text { years or } \\
\text { more live in your household? }\end{array}$ & Exact number \\
\hline Village & Would you say you are living in... & Rural area $=1 ;$ Other $=0$ \\
\hline City & Would you say you are living in... & City $=1 ;$ Other $=0$ \\
\hline $\begin{array}{l}\text { Parents } \\
\text { Self-employed }\end{array}$ & Could you tell me the occupations of your parents? & $\begin{array}{l}\text { Father or Mother are/were self-employed }= \\
1 ; \text { Other }=0\end{array}$ \\
\hline $\begin{array}{l}\text { Factor 1: Skills \& } \\
\text { knowledge gained in } \\
\text { education (a combination } \\
\text { of four variables into one } \\
\text { factor - using the factor } \\
\text { analysis) }\end{array}$ & $\begin{array}{l}\text { Please tell me if you totally agree, tend to agree, tend to disagree or totally } \\
\text { disagree with each of following } \\
\text { statements: }\end{array}$ & The output variable from factor analysis \\
\hline
\end{tabular}




\begin{tabular}{|c|c|c|}
\hline Variable & Description of question & Coding \\
\hline Skills and know-how & $\begin{array}{l}\text { My school education has given me skills and know-how to enable me to run a } \\
\text { business }\end{array}$ & \multirow{4}{*}{$\begin{array}{l}\text { Totally agree }=4 \\
\text { Tend to agree }=3 \\
\text { Tend to disagree }=0 \\
\text { Totally disagree }=1\end{array}$} \\
\hline Entrepreneurial attitude & $\begin{array}{l}\text { My school education has helped me to develop my sense of initiative and a } \\
\text { sort of entrepreneurial attitude }\end{array}$ & \\
\hline Interest & My school education has made me interested in becoming an entrepreneur & \\
\hline Understand the role & $\begin{array}{l}\text { My school education has helped me to better understand the role of } \\
\text { entrepreneurs in society }\end{array}$ & \\
\hline
\end{tabular}

Source: Authors based on data from flash Eurobarometer 354 (2013).

\section{Acknowledgement}

This research was supported by the Slovak Research and Development Agency (APVV), APVV-14-0512 "Universities and regional development".

We would like to thank reviewers for their detailed comments and suggestions for the manuscript.

\section{References}

Ajzen, I. (1991). The theory of planned behavior. Organizational behavior and human decision processes, 50(2), 179-211. https://doi.org/10.1016/0749-5978(91)90020-T

Arbo, P., \& Benneworth, P. (2007). Understanding the regional contribution of higher education institutions: A literature Review. Paris: OECD publishing. OECD Education Working Papers No. 170. https://doi.org/10.1787/19939019

Badinger, H., \& Tondl, G. (2003). Trade, human capital and innovation: the engines of European regional growth in the 1990s. In E. Fingleton (Ed), European regional growth (pp. 215-239) Heidelberg: Springer Berlin. https://doi.org/10.1007/978-3-662-07136-6_8

Bartos, P., Rahman, A., Horak, J., \& Jacova, H. (2015). Education and entrepreneurship in the SME segment in economic transformation. Economics \& Sociology, 8(2), 227-239. https://doi.org/10.14254/2071-789X.2015/8-2/16

Cooper, S. Y., \& Park, J. S. (2008). The impact of 'incubator' organizations on opportunity recognition and technology innovation in new, entrepreneurial high-technology ventures. International Small Business Journal, 26(1), 27-56. https://doi.org/10.1177/0266242607084658

Daghbashyan, Z., \& Harsman, B. (2014). University choice and entrepreneurship. Small Business Economics, 42(4), 729746. https://doi.org/10.1007/s11187-013-9501-0

Dutta, D. K., Li, J., \& Merenda, M. (2011). Fostering entrepreneurship: impact of specialization and diversity in education. International Entrepreneurship and Management Journal, 7(2), 163-179. https://doi.org/10.1007/s11365-010-0151-2

Elston, J. A., \& Audretsch, D. B. (2011). Financing the entrepreneurial decision: an empirical approach using experimental data on risk attitudes. Small business economics, 36(2), 209-222. https://doi.org/10.1007/s11187-009-9210-x

Enders, J. (2010) Higher education and the labor market. In P. Peterson, E. Baker, B. McGaw, (Eds.) International Encyclopedia of Education (pp. 365-369). Oxford: Elsevier, 365-369. https://doi.org/10.1016/B978-0-08-0448947.00827-7

Evans, D. S., \& Jovanovic, B. (1989). An estimated model of entrepreneurial choice under liquidity constraints. Journal of political economy, 97(4), 808-827. https://doi.org/10.1086/261629

Gupta, V. K., \& York, A. S. (2008). The effects of geography and age on women's attitudes towards entrepreneurship Evidence from the state of Nebraska. The International Journal of Entrepreneurship and Innovation, 9(4), 251-262. https://doi.org/10.5367/000000008786208777

Ionescu, A. M. (2012). How does education affect labour market outcomes?. Review of Applied Socio-Economic Research, $4(2), 130-144$.

Kolstad, I., \& Wiig, A. (2015). Education and entrepreneurial success. Small Business Economics, 44(4), 783-796. https://doi.org/10.1007/s11187-014-9621-1

Kuratko, D. F. (2005). The emergence of entrepreneurship education: Development, trends, and challenges. Entrepreneurship theory and practice, 29(5), 577-598. https://doi.org/10.1111/j.1540-6520.2005.00099.x

Kuttim, M., Kallaste, M., Venesaar, U., \& Kiis, A. (2014). Entrepreneurship education at university level and students' entrepreneurial intentions. Procedia-Social and Behavioral Sciences, 110, 658-668. https://doi.org/10.101 6/j.sbspro.2013.12.910

Lee, S. M., Chang, D., \& Lim, S. B. (2005). Impact of entrepreneurship education: A comparative study of the US and Korea. The International Entrepreneurship and Management Journal, 1(1), 27-43. https://doi.org/10.1007/s11365005-6674-2

Lekovic, B., Maric, S., \& Lekovic, B. (2014). Characteristics of Entrepreneurial Activities in Transitional Countries and Their Influence on Development. Inzinerine Ekonomika-Engineering Economics, 25(1), 62-71. https://doi.org/10.57 55/j01.ee.25.1.2885 
Levesque, M., \& Minniti, M. (2006). The effect of aging on entrepreneurial behavior. Journal of Business Venturing, 21(2), 177-194. https://doi.org/10.1016/j.jbusvent.2005.04.003

Ling, H., \& Venesaar, U. (2015). Enhancing Entrepreneurship Education in Engineering Students to Increase Their Metacognitive Abilities: Analysis of Student Self-Assessments. Inzinerine Ekonomika-Engineering Economics, 26(3), 333-342. https://doi.org/10.5755/j01.ee.26.3.5283

Lucas, R. E. (1978). On the size distribution of business firms. The Bell Journal of Economics, 9(2), 508-523. https://doi.org/10.2307/3003596

Masakure, O. (2015). Education and entrepreneurship in Canada: evidence from (repeated) cross-sectional data. Education Economics, 23(6), 693-712. https://doi.org/10.1080/09645292.2014.891003

Mavromaras, K., McGuinness, S., O'Leary, N., Sloane, P., \& Wei, Z. (2013). Job mismatches and labour market outcomes: panel evidence on university graduates. Economic Record, 89(286), 382-395. https://doi.org/10.1111/14754932.12054

Minniti, M., \& Nardone, C. (2007). Being in someone else's shoes: the role of gender in nascent entrepreneurship. Small Business Economics, 28(2/3), 223-238. https://doi.org/10.1007/s11187-006-9017-y

Mincer, J. (1991). Human capital, technology, and the wage structure: what do time series show? NBER working paper No. 3581. National Bureau of Economic Research. doi: 10.3386/w3581

Nabi, G., Walmsley, A., Linan, F., Akhtar, I., \& Neame, C. (2016). Does entrepreneurship education in the first year of higher education develop entrepreneurial intentions? The role of learning and inspiration. Studies in Higher Education, 1-16. https://doi.org/10.1080/03075079.2016.1177716

Naser, K., Rashid Mohammed, W., \& Nuseibeh, R. (2009). Factors that affect women entrepreneurs: evidence from an emerging economy. International Journal of Organizational Analysis, 17(3), 225-247. https://doi.org/10.1108/1 9348830910974932

Nunez, I., \& Livanos, I. (2010). Higher education and unemployment in Europe: an analysis of the academic subject and national effects. Higher Education, 59(4), 475-487. https://doi.org/10.1007/s10734-009-9260-7

Peterman, N. E., \& Kennedy, J. (2003). Enterprise education: Influencing students' perceptions of entrepreneurship. Entrepreneurship theory and practice, 28(2), 129-144. https://doi.org/10.1046/j.1540-6520.2003.00035.x

Pittaway, L., \& Cope, J. (2007). Entrepreneurship education: a systematic review of the evidence. International small business journal, 25(5), 479-510. https://doi.org/10.1177/0266242607080656

Rantanen, T., Pawlak, A., \& Toikko, T. (2015). The Significance of Social Welfare Attitudes in Young People's Entrepreneurial Intentions. Entrepreneurial Business and Economics Review, 3(1), 43-60. https://doi.org/10.15678/E BER.2015.030104

Robinson, P. B., \& Sexton, E. A. (1994). The effect of education and experience on self-employment success. Journal of business Venturing, 9(2), 141-156. https://doi.org/10.1016/0883-9026(94)90006-X

Sterlacchini, A. (2008). R\&D, higher education and regional growth: Uneven linkages among European regions. Research Policy, 37(6), 1096-1107. https://doi.org/10.1016/j.respol.2008.04.009

Strauf, S., \& Scherer, R. (2008). Universities and their contribution to regional development. Transformations in Business \& Economics, 7 (1), 137-151.

Thompson, P., Jones-Evans, D., \& Kwong, C. C. (2010). Education and entrepreneurial activity: A comparison of White and South Asian Men. International Small Business Journal, 28(2), 147-162. https://doi.org/10.1177/02 66242609355858

Turker, D., \& Sonmez Selcuk, S. (2009). Which factors affect entrepreneurial intention of university students?. Journal of European Industrial Training, 33(2), 142-159. https://doi.org/10.1108/03090590910939049

Van der Sluis, J., Van Praag, M., \& Vijverberg, W. (2008). Education and entrepreneurship selection and performance: A review of the empirical literature. Journal of economic surveys, 22(5), 795-841. https://doi.org/10.1111/j.14676419.2008.00550.x

Van Praag, C. M., \& Cramer, J. S. (2001). The roots of entrepreneurship and labour demand: Individual ability and low risk aversion. Economica, 68(269), 45-62. https://doi.org/10.1111/1468-0335.00232

Wach, K., \& Wojciechowski, L. (2016). Entrepreneurial Intentions of Students in Poland in the View of Ajzen's Theory of Planned Behaviour. Entrepreneurial Business and Economics Review, 4(1), 83-94. https://doi.org/10.15678/E BER.2016.040106

Wang, C. K., \& Wong, P. K. (2004). Entrepreneurial interest of university students in Singapore. Technovation, 24(2), 163172. https://doi.org/10.1016/S0166-4972(02)00016-0

The article has been reviewed.

Received in September, 2017; accepted in April, 2018. 